\title{
Variasi genetik dan jarak genetik suku Sakai di Provinsi Riau dengan suku Minangkabau di Desa Pagaruyung Sumatera Barat berdasarkan DNA mikrosatelit
}

\author{
Genetic variation and genetic distance of the Sakai tribe in Riau Province and the \\ Minangkabau tribe in Pagaruyung Village, West Sumatra based on microsatellite DNA
}

\author{
Tyara*, I Ketut Junitha, Ni Nyoman Wirasiti \\ Program Studi Biologi, Fakultas Matematika dan Ilmu Pengetahuan Alam, Universitas Udayana, \\ Bukit Jimbaran, Bali, Indonesia - 80361 \\ *Email: tyara@student.unud.ac.id
}

Diterima 23 Nopember $2020 \quad$ Disetujui 25 Januari 2021

\section{INTISARI}

Terdapat beberapa versi yang menjelaskan mengenai asal-usul suku Sakai baik secara literatur ataupun cerita-cerita yang berkembang dan diturunkan sejak dahulu. Masyarakat Sakai sendiri meyakini bahwa leluhur mereka berasal dari sebuah nagari bernama Pagaruyung di Provinsi Sumatera Barat. Oleh karena itu, penelitian ini bertujuan untuk mengetahui variasi dan jarak genetik masyarakat suku Sakai di Provinsi Riau dengan suku Minangkabau di Desa Pagaruyung Provinsi Sumatera Barat berdasarkan tiga lokus DNA mikrosatelit (D2S1338, D16S539 dan D13S317). Ditemukan total 10 ragam alel yang tersebar dalam tiga lokus DNA mikrosatelit suku Sakai dan 11 ragam alel pada suku Minangkabau. Hasil analisis data menggunakan software GenAlex 6.503 diperoleh nilai heterozigositas pada suku Sakai dan suku Minangkabau tergolong sedang dengan nilai 0,557 \pm 0,062 pada Suku Sakai dan 0,615 \pm 0,073 pada suku Minangkabau. Begitu pula dengan nilai diferensiasi genetik $\left(F_{\text {ST }}\right)$ pada kedua suku ini juga menunjukkan perbedaan genetik yang sedang $(0,088 \pm 0,039)$. Berdasarkan nilai $F$ 'sT dan nilai heterozigositas dari tiga lokus DNA mikrosatelit ini maka dapat dikatakan bahwa suku Sakai dan suku Minangkabau memiliki kemiripan secara genetik. Hal ini didukung dengan adanya aliran keluar atau masuknya alel pada suku Sakai dan suku Minangkabau dengan laju migrasi sebanyak empat orang setiap generasi sehingga secara genetik suku Sakai dan suku Minangkabau memiliki kemiripan dengan jarak genetik sebesar 0,269 dan besarnya proporsi gen yang identik (Genetic identity) sebesar 0,764.

Kata kunci: DNA Mikrosatelit, jarak genetic, suku Minangkabau, suku Sakai, variasi genetik

\begin{abstract}
There are several versions can explain the origin of the Sakai tribe. Sakai people themselves believe that their ancestors came from Pagaruyung, West Sumatra Province. The purpose of this research is to determine the genetic variation and genetic distance of the Sakai tribe in Riau Province and the Minangkabau tribe in Pagaruyung Village, West Sumatra Province based on three microsatellite DNA loci (D2S1338, D16S539, and D13S317). A total of 10 alleles were found in three microsatellite loci of the Sakai tribe and 11 alleles in the Minangkabau tribe. Data analysis using GenAlex 6.503 software showed that the heterozygous value of the Sakai and Minangkabau tribes was moderate with a value of $0.557 \pm 0.062$ in the Sakai tribe and $0.615 \pm 0.073$ in the Minangkabau tribe. Meanwhile, the value of genetic differentiation (F'sT) in these two tribes shows moderate genetic differences $(0.088 \pm 0.039)$. Genetically, Sakai people and Minangkabau
\end{abstract}


tribes have similarities based on the D2S1338, D16S539, and D13S317 microsatellite DNA loci with a genetic distance of 0.269 and the proportion of identical genes (Genetic identity) of 0.764 . This result is supported by alleles outflow or entry in the Sakai and Minangkabau tribes with a migration rate is four people per generation.

Keywords: Microsatellite DNA, genetic distance, Minangkabau tribe, Sakai tribe, genetic variation

\section{PENDAHULUAN}

Keberadaan suku Sakai identik dengan sistem hidup nomaden di pedalaman hutan (Sofyan, 2012), sistem ladang berpindah-pindah (banjar ladang) dan merupakan satu-satunya suku asli di Riau yang hingga kini masih memiliki hak ulayat atas tanah dan hutan Riau (Kurtubi, 2017). Akan tetapi, akibat alih fungsi lahan hutan yang akhirakhir ini marak terjadi di Riau, menyebabkan masyarakat suku Sakai yang hidupnya dahulu sangat bergantung pada hasil hutan dan sungai dipaksa untuk terus bertahan ditengah keterbatasan dengan mendirikan perkampungan asli orang Sakai di pinggiran hutan Riau. Saat ini orang Sakai telah hidup membaur dengan kebudayaan Melayu dan suku pendatang lain di sekelilingnya dan mulai terlepas dari keterisolasian (Daldjoeni, 1991).

Mengenai persebaran suku Sakai di Provinsi Riau, Agnes dan Ahmad (2007) menyebutkan bahwa suku Sakai tersebar dan dapat dijumpai di beberapa wilayah meliputi Minas, Belutu, Tingaran, Sinangan, Semunai, Panaso dan Borumban. Menurut data kependudukan yang dikeluarkan oleh Departemen Sosial Republik Indonesia pada tahun 2015, populasi suku Sakai di Provinsi Riau paling banyak dijumpai di Kabupaten Bengkalis yaitu sebanyak 9.953 jiwa. Kemudian pada tahun 2015 lalu, Direktorat Pemberdayaan Komunitas Adat Terpencil resmi memasukkan suku Sakai kedalam Komunitas Adat Terpencil (KAT) di Provinsi Riau (Nur'aisyah, 2017; Kurtubi, 2017).

Terdapat dua versi yang dapat menjelaskan mengenai asal usul suku Sakai. Lutfi (1977) menuliskan bahwa orang Sakai merupakan percampuran antara orang weddoid yang telah terlebih dahulu mendiami Riau dengan orang Proto melayu yang datang pada saat gelombang kedatangan melayu pertama di Indonesia. Sedangkan berdasarkan versi para tetua Sakai dalam Suparlan (1995) menuliskan bahwa suku Sakai berasal dari orang Pagaruyung yang bermigrasi ke tepian Sungai Gasib di Provinsi Riau. Pagaruyung merujuk pada sebuah daerah pusat kerajaan yang merupakan daerah pusat adat dan budaya bagi suku Minangkabau. Saat ini salah satu sisa peninggalan sejarah Kerajaan Minangkabau yang berpusat di Pagaruyung ini dapat dijumpai di Kabupaten Tanah Datar Provinsi Sumatera Barat (Pasaribu, 2019).

Seiring berjalannya waktu, orang Sakai dan orang Minangkabau dari Pagaruyung ini akan terus melanjutkan keturunannya. Akibat penurunan sifat dari leluhur mereka yang diturunkan secara turun temurun, dan adanya perbedaan respon masing-masing individu terhadap lingkungannya serta mutasi yang terjadi seiring berjalannya waktu, maka akan terjadi suatu variasi genetik (Junitha \& Watiniasih, 2014). Variasi genetik ini dapat dilihat dengan menggunakan sebuah penanda molekuler yang disebut dengan DNA mikrosatelit. Mikrosatelit memiliki variabilitas yang tinggi dikarenakan memiliki rata-rata kecepatan mutasi yang tinggi serta mudah dan tidak terlalu mahal untuk dianalisis dengan menggunakan Polymerase Chain Reaction (PCR) (Moeljopawiro, 2010). Melalui polimorfisme mikrosatelit ini, maka keragaman genetik suatu populasi dapat diketahui (Muladno, 2000). Saat ini penelitian mengenai variasi dan jarak genetik masyarakat suku Sakai masih belum dilakukan, sehingga penelitian ini diharapkan dapat menjadi studi awal mengenai keragaman genetik yang menyusun masyarakat suku Sakai berdasarkan tiga lokus DNA mikrosatelit (D2S1338, D16S539 dan D13S317). 


\section{MATERI DAN METODE}

\section{Tempat dan waktu penelitian}

Sampel diambil menggunakan teknik Purposive Sampling, yaitu pengambilan sampel ditujukan khusus kepada masyarakat suku Sakai di Kabupaten Bengkalis Provinsi Riau dan masyarakat suku Minangkabau di Kabupaten Tanah Datar Provinsi Sumatera Barat dengan metode non invasive sampling (sampel diambil tanpa melukai probandus). Pengambilan sampel DNA suku Sakai dilakukan di enam pemukiman Sakai yaitu Kelurahan Pematang Pudu, Kelurahan Air Jamban, Desa Semunai, Desa Sialang Rimbun, Desa Muara Basung, dan Desa Kesumbo Ampai di Kabupaten Bengkalis Provinsi Riau pada bulan Desember 2018-Januari 2019. Adapun untuk pengambilan sampel DNA pada suku Minangkabau diambil di desa Pagaruyung Kecamatan Tanjung Emas Kabupaten Tanah Datar Provinsi Sumatera Barat pada bulan November 2018 - Januari 2019. Pelaksanaan ekstraksi DNA, PCR, elektroforesis hingga visualisasi pita-pita DNA hasil PCR dilaksanakan di Laboratorium Serologi dan DNA Forensik UPT Forensik Universitas Udayana dan Laboratorium Biologi Sel dan Molekuler Fakultas Kedokteran Universitas Udayana Bali.

\section{Kriteria probandus}

Sampel DNA yang diambil dari probandus berupa sel epitel mukosa mulut yang berasal dari 30 orang probandus suku Minangkabau dan 30 orang probandus suku Sakai yang tidak memiliki hubungan kekeluargaan dan tidak melakukan perkawinan campur antar suku melalui pengisian data silsilah dua keturunan diatas probandus dari garis keturunan ayah kandung maupun ibu kandung yang meliputi data asal suku. Hal ini bertujuan untuk melihat identitas keetnisannya probandus.

\section{Teknik pengambilan sampel}

Sebelum dilakukan pengambilan sampel, calon probandus terlebih dahulu diberikan penjelasan terkait tujuan penelitian dan prosedur pengambilan sampel. Bagi calon probandus yang bersedia menjadi probandus, selanjutnya dilakukan pengisian biodata serta pengisian lembaran informed consent. Selanjutnya sampel sel epitel mukosa mulut diambil dengan cara pengusapan cotton bud steril di dinding pipi bagian dalam probandus. Kemudian tangkai cotton bud diputar-putar dalam tabung 1,5 mL yang telah diisi $500 \mu \mathrm{L}$ buffer lysis Urea DPZ (10 $\mathrm{mM} \mathrm{NaCl}+100 \mathrm{mM}$ EDTA + $100 \mathrm{mM}$ Tris-Cl + Urea $4 \mathrm{M}+$ Aquades) agar sel-sel epitel yang menempel terlepas (Junitha \& Sudirga, 2007).

\section{Ekstraksi dan amplifikasi DNA}

DNA diekstraksi dengan metode fenolkloroform yang dimodifikasi tanpa penambahan proteinase-K dan tanpa proses inkubasi pada suhu $55^{\circ} \mathrm{C}$ (Junitha \& Sudirga, 2007). Modifikasi metode ini merupakan penyederhanaan prosedur ekstraksi DNA dengan menggabungkan metode ekstraksi DNA dan purifikasi fenol/kloroform. Dalam metode ini, untuk mengekstrak DNA tanpa proses inkubasi dan penambahan proteinase $\mathrm{K}$, maka ditambahkan SDS dan urea kedalam buffer yang berfungsi sebagai bahan pelisis sel (Nanasato et al., 2018).

DNA yang telah diesktraksi selanjutnya diamplifikasi menggunakan mesin PCR SenscQuest Labcycler dengan tiga primer lokus DNA Mikrosatelit D2S1338, D16S539 dan D13S317 seperti yang tersaji pada Tabel 1. Penggunaan ketiga primer ini selain agar dapat dibandingkan dengan peneltian-penelitian mengenai genetik suku bangsa yang menggunakan tiga lokus yang sama, juga dikarenakan adanya keterbatasan dana dan waktu penelitian. Selanjutnya larutan pereaksi PCR dibuat dari PCR mix Go-Taq ${ }^{\circledR}$ Green sebanyak 6,5 $\mu \mathrm{L}$ ditambahkan dengan 3,5 $\mu \mathrm{L}$ air steril, $1 \mu \mathrm{L}$ primer dan 2,0 $\mu \mathrm{L}$ sampel DNA dengan volume total $13 \mu \mathrm{L}$. Aktivitas mesin PCR dijalankan dengan program pra denaturasi dengan suhu $95^{\circ} \mathrm{C}$ selama 5 menit, suhu denaturasi sebesar $95^{\circ} \mathrm{C}$ selama 45 detik, untuk suhu annealing pada masing-masing lokus (Tabel 1) selama 1 menit dan untuk fase extension pada suhu $72{ }^{\circ} \mathrm{C}$ selama 1 menit 15 detik. Ketiga fase ini diakukan 
pengulangan sebanyak 30 siklus. Kemudian dilanjutkan dengan fase post-extension DNA dengan suhu $72{ }^{\circ} \mathrm{C}$ selama 5 menit dan diikuti tahap penyesuaian penyimpanan dengan suhu 4 ${ }^{\circ} \mathrm{C}$ (Arnila dkk., 2016).

Tabel 1. Primer yang digunakan dalam analisis mikrosatelit

\begin{tabular}{cccc}
\hline Lokus & $\begin{array}{c}\text { Reverse } \\
\left(\mathbf{5} \boldsymbol{\rightarrow} \rightarrow \mathbf{3}^{\prime}\right)\end{array}$ & $\begin{array}{c}\text { Forward } \\
(\mathbf{5} \boldsymbol{\rightarrow} \rightarrow \mathbf{3})\end{array}$ & $\begin{array}{c}\text { Suhu } \\
\text { Annealing }\end{array}$ \\
\hline D2S1338 & ACCTAGCATGGTACCTGCAG & CCAGTGGATTTGGAAACAGA & $53^{\circ} \mathrm{C}$ \\
D13S317 & GCCCAAAAAGACAGACAGAA & ACAGAAGTCTGGGATGTGA & $63^{\circ} \mathrm{C}$ \\
D16S539 & ACGTTTGTGTGTGCATCTGT & GATCCCAAGCTCTTCCTCTT & $64^{\circ} \mathrm{C}$ \\
\hline
\end{tabular}

\section{Elektroforesis dan visualisasi DNA hasil PCR}

Elektroforesis DNA hasil PCR dilakukan pada mesin elektroforesis dengan matriks Polyacrilamide Gel Electrophoresis (PAGE) $10 \%$ volume $7 \mathrm{~mL}$ selama 70 menit dengan tegangan 160 volt (Junitha \& Octavia. 2015; Laksmita dkk., 2015). Selanjutnya untuk melihat migrasi pita-pita amplikon pada gel akrilamid, maka gel diwarnai dengan gel red dan visualisasi pita-pita DNA dilihat dengan menggunakan alat UV Transilluminators. Migrasi pita-pita amplikon pada gel akrilamid ini diukur menggunakan marker 100bp DNA ladder dan selanjutnya diplot pada kertas semilog sebagai alel dalam satuan panjang basa (pb) (Hutchinson, 2001).

\section{Analisis data}

Data hasil penelitian dalam bentuk ukuran alel dianalisis dengan menggunakan software GenAlEx 6.503 (Peakall dan Smouse, 2012) untuk memperoleh informasi mengenai frekuensi alel, nilai heterozigositas diamati (Ho), Heterozigositas diharapkan (He), nilai diferensiasi genetik (F'st), laju migrasi (Nm), jarak genetik (Nei's Genetic Distance) dan Genetic Identity untuk melihat keragaman genetic suku Sakai dan suku Minangkabau serta jarak genetik dan laju migrasi antar kedua suku ini (Nei, 1987).

\section{HASIL}

Dari semua sampel DNA probandus suku Minangkabau dan suku Sakai yang diekstraksi, tidak semua sampel yang berhasil teramplifikasi pada tiga lokus mikrosatelit (Tabel 2). Sampelsampel yang tidak berhasil diamplifikasi pada tiga lokus DNA mikrosatelit (D2S1338, D16S539 dan D13S317) dapat disebabkan oleh beberapa faktor seperti kondisi probandus, pengaruh suhu annealing pada saat PCR, maupun mutasi (Dwitiari, 2012; Damayanti dkk.,2014; Junitha dan Octavia, 2015). Pada lokus D2S1338 diperoleh sebanyak empat ragam alel, dengan alel terpendek berukuran $177 \mathrm{bp}$ dan alel terpanjang berukuran 197 bp (Gambar 1a). Kemudian untuk total sampel suku Sakai dan suku Minangkabau dari lokus D16S539 yang berhasil diamplifikasi diperoleh sebanyak enam ragam alel, dengan alel terpendek berukuran 148 bp dan alel terpanjang berukuran 176 bp (Gambar 1b). Sedangkan pada lokus D13S317 diperoleh tiga ragam alel, dengan alel terpendek berukuran 180 bp dan alel terpanjang berukuran 192 bp (Gambar 1c).

Tabel 2. Jumlah Sampel yang berhasil dan tidak berhasil diamplifikasi pada lokus D2S1338, D16S539 dan D13S317.

\begin{tabular}{ccccc}
\hline \multirow{2}{*}{ Lokus } & \multicolumn{2}{c}{ Suku Minangkabau } & \multicolumn{2}{c}{ Suku Sakai } \\
\cline { 2 - 5 } & Teramplifikasi & $\begin{array}{c}\text { Tidak } \\
\text { Teramplifikasi }\end{array}$ & Teramplifikasi & $\begin{array}{c}\text { Tidak } \\
\text { Teramplifikasi }\end{array}$ \\
\hline D2S1338 & 28 & 2 & 28 & 2 \\
D16S539 & 27 & 3 & 26 & 4 \\
D13S317 & 24 & 6 & 23 & 7 \\
\hline
\end{tabular}




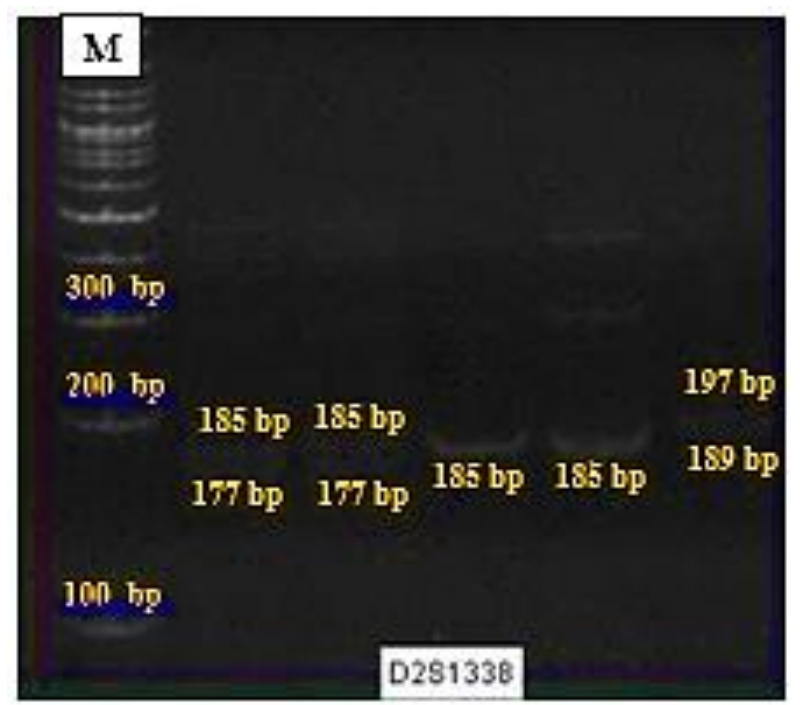

(a)

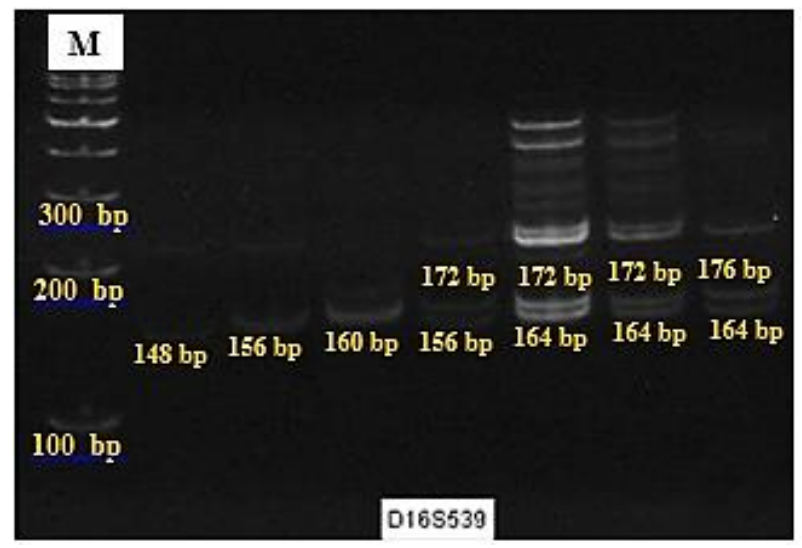

(b)

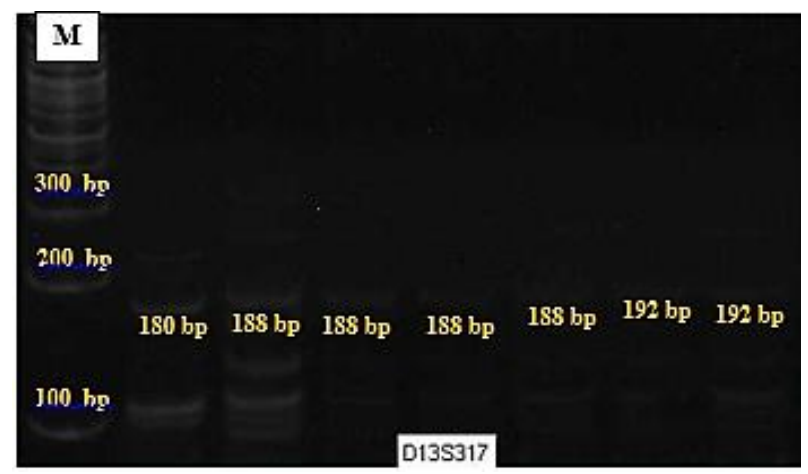

(c)

Gambar 1. Hasil visualisasi amplikon dengan menggunakan gel elektroforesis poliakrilamid 10\% (a) Pada lokus D2S1338, (b) Pada lokus D16S539 dan (c) Pada lokus D13S317.

Pada tiga lokus DNA mikrosatelit suku Sakai dan suku Minangkabau yang telah diamplifikasi, ditemukan ale-alel yang bervariasi dengan penyebaran yang dapat dikatakan masih belum merata. Ketidakmerataan penyebaran alel dalam tiga lokus DNA mikrosatelit ini disebabkan karena adanya alel yang mendominasi pada masing-masing lokus. Seperti yang diketahui, lokus D13S317 pada suku Sakai dan suku Minangkabau memiliki frekuensi alel diatas 50\% yang terdapat pada alel $192 \mathrm{bp}(0,652)$ pada suku Sakai dan alel 188 bp $(0,688)$ pada suku Minangkabau (Tabel 3). Menurut Junitha \& Yossy (2016), apabila ragam alel semakin banyak dan frekuensi alel pada masing-masing lokus semakin merata maka akan semakin memperkecil hubungan kekerabatan satu individu dengan individu lainnya, dan apabila semakin merata frekuensi suatu alel dalam setiap lokus maka akan semakin baik digunakan untuk kepentingan analisis DNA.

Tabel 3. Variasi dan frekuensi alel pada suku Sakai dan suku Minangkabau dalam tiga lokus (D2S1338, D16S539 dan D13S317) DNA mikrosaelit

\begin{tabular}{lccc}
\hline \multirow{2}{*}{ Lokus } & Alel & \multicolumn{2}{c}{ Frekuensi Alel } \\
\cline { 3 - 4 } & & $\begin{array}{c}\text { Suku } \\
\text { Sakai }\end{array}$ & $\begin{array}{c}\text { Suku } \\
\text { Minangkabau }\end{array}$ \\
\hline D2S1338 & 177 & 0,464 & 0,268 \\
& 185 & 0,482 & 0,357 \\
& 189 & 0,036 & 0,232 \\
D16S539 & 197 & 0,018 & 0,143 \\
& 148 & 0,077 & \\
& 156 & 0,154 & \\
& 160 & & 0,333 \\
& 164 & 0,442 & 0,463 \\
& 172 & 0,327 & 0,185 \\
D13S317 & 176 & & 0,019 \\
& 180 & & 0,146 \\
& 188 & 0,348 & 0,688 \\
& 192 & 0,652 & 0,167 \\
\hline
\end{tabular}

Hasil analisis rata-rata nilai heterozigositas diamati (Ho) dan heterozigositas diharapkan (He) pada Tabel 4 menunjukkan adanya penurunan nilai heterozigositas pada suku Minangkabau, dimana nilai Ho $<\mathrm{He}(0.435 \pm 0.106<0.615 \pm$ 0.073). Sebaliknya pada suku Sakai Ho > He $(0.636 \pm 0.166>0.557 \pm 0.062)$. Sedangkan perolehan nilai F'st antara kedua suku ini menunjukkan perbedaan genetik yang sedang berdasarkan pengelompokkan Nei (1973) yaitu sebesar $0.088 \pm 0.039$ dan perolehan laju migrasi (Nm) diketahui sebanyak empat orang per generasi $(3.729 \pm 1.348)$. Adapun untuk jarak genetik dan genetic identity berturut-turut sebesar 0,269 dan 0,764 . 
Tabel 4. Rata-rata nilai Ho, He, F’ST, Nm, Jarak Genetik dan Genetic Identity pada suku Minangkabau dan suku Sakai

\begin{tabular}{ccc}
\hline & Suku Minangkabau & Suku Sakai \\
\hline Heterozigositas diamati (Ho) & $0,435 \pm 0,106$ & $0,636 \pm 0,166$ \\
Heterozigositas diharapkan (He) & $0,615 \pm 0,073$ & $0,557 \pm 0,062$ \\
Diferensiasi genetik (F'sT) & $0,088 \pm 0,039$ \\
Laju migrasi (Nm) & $3,729 \pm 1,348$ \\
Jarak Genetik & 0,269 \\
Genetic Identity & \multicolumn{2}{c}{0,764} \\
\hline
\end{tabular}

\section{PEMBAHASAN}

Total ragam alel yang diperoleh dari hasil pengukuran migrasi DNA yang berhasil diamplifikasi yaitu sebanyak 10 ragam alel pada suku Sakai dan 11 ragam alel suku Minangkabau yang terdistribusi kedalam tiga lokus DNA mikrosatelit yang polimorfik (lokus D2S1338, D16S539 dan D13S317). Apabila dibandingkan dengan penelitian dari beberapa etnis lain dengan menggunakan lokus DNA mikrosatelit yang sama, suku Sakai dan suku Minangkabau diketahui memiliki total ragam alel yang lebih sedikit. Beberapa penelitian tersebut diantaranya yaitu penelitian yang telah dilakukan oleh Unadi dkk. (2010) pada suku Batak diperoleh sebanyak 32 ragam alel, penelitian oleh Octavia dkk (2015) pada suku Dayak Kaharingan diperoleh sebanyak 29 ragam alel, penelitian pada etnis Filipina oleh Rodriguez et al (2015) sebanyak 26 ragam alel dan penelitian pada etnis melayu (Maruyama et al., 2008) sebanyak 27 ragam alel. Variasi banyaknya ragam alel dan pemerataan persebaran frekuensi alel pada masing-masing lokus ini akan berkorelasi terhadap nilai keragaman genetik. Apabila semakin banyak ragam alel pada setiap lokus, maka nilai keragaman genetika akan semakin tinggi (Junitha \& Alit, 2011; Junitha \& Yossy, 2016).

Pada penelitian ini diperolehan panjang alel suku Sakai dan suku Minangkabau pada lokus D2S1338 berkisaran antara 177 bp - 197 bp. Kisaran panjang alel yang ditemukan pada suku Sakai dan suku Minangkabau ini masih berada didalam kisaran panjang alel yang sama dengan beberapa suku bangsa di Indonesia diantaranya yaitu suku Batak berkisar 157 bp-209 bp (Unadi dkk., 2010), suku Dayak Kaharingan berkisar antara 157 bp-205 bp (Octavia dkk., 2015) maupun suku Bali dengan panjang alel berkisar antara 165 bp-185 bp (Laksmita dkk., 2015). Hal yang sama juga terlihat pada lokus D16S317 dan D13S317 pada suku Sakai dan suku Minangkabau. Diketahui kisaran panjang alel suku Sakai yaitu 148 bp-172 bp pada lokus D16S539 dan 188 bp- 192 bp pada lokus D13S317, serta kisaran panjang alel suku Minangkabau yang berkisar $160 \mathrm{bp}-176 \mathrm{bp}$ bp pada lokus D16S539 dan 180 bp-192 bp pada lokus D113S317 juga dapat dikatakan masih berada dikisaran yang sama dengan suku Batak (Unadi dkk., 2010), suku Dayak Kaharingan (Octavia dkk., 2015) maupun suku Bali (Laksmita dkk., 2015).

Kemiripan kisaran ukuran alel pada tiga lokus mikrosatelit ini menunjukkan bahwa suku Sakai dan suku Minangkabau masih berada dalam kisaran alel-alel suku bangsa di Indonesia. Artinya, alel-alel yang diperoleh pada penelitian tiga lokus DNA mikrosatelit suku Sakai dan suku Minangkabau ini juga dapat ditemukan dan tersebar dalam keturunan kelompok ProtoMelayu seperti suku Batak maupun suku Dayak serta keturunan kelompok Deutero-Melayu seperti suku Bali. Persebaran alel ini berkaitan dengan proses kedatangan gelombang kelompok manusia proto melayu dan deutero melayu di Indonesia yang menjadi dasar akar budaya dan suku-suku bangsa di Indonesia. Adanya variasi alel pada lokus yang sama antara suku Sakai dan suku Minangkabau dengan suku-suku lainnya di Indonesia ataupun dengan etnis melayu dan etnis 
Filipina, dapat dipengaruhi oleh mutasi dan migrasi. Mutasi yang terjadi dapat memunculkan alel-alel baru sehingga terjadinya keragaman genetik. Akibat adanya variasi yang tidak sama antar populasi ini, maka akan menimbulkan suatu karakteristik unik yang akan menjadi pembeda satu populasi dengan populasi lainnya (Butler, 2006).

Pada lokus D2S1338, diketahui bahwa alel 185 bp pada kedua suku Sakai dan suku Minangkabau ini memiliki frekuensi tertinggi yang sama, dengan besar frekuensi berturut-turut 0,482 pada suku Sakai serta 0,357 pada suku Minangkabau. Penelitian yang dilakukan oleh Laksmita dkk (2015) pada suku Bali juga ditemukan hal yang serupa, dimana diketahui bahwa alel 185 bp juga memiliki frekuensi tertinggi sebesar 0,4957. Begitu halnya pada lokus D16S539, dimana suku Sakai dan suku Minangkabau memiliki frekuensi alel tertinggi yang sama yaitu pada alel $164 \mathrm{bp}$. Ditemukannya alel dengan frekuensi tertinggi yang sama pada lokus D2S1338 (alel 185 bp) dan lokus D16S539 (alel 164 bp) pada kedua suku ini menunjukkan bahwa suku Sakai dan suku Minangkabau memiliki alel awal (founding father) yang sama. Alel-alel founding father ini kemudian seiring berjalannya waktu dan berkembangnya kedua suku ini dapat mengalami mutasi bertahap menjadi alel-alel lainnya atau bahkan menghilangkan alel yang lama dengan menghasilkan alel-alel baru (Gonser et al., 2000; Junitha, 2004).) Oleh karena itu, terdapat beberapa alel yang ditemukan pada suku Sakai tetapi tidak ditemukan pada suku Minangkabau begitu pun sebaliknya sehingga hal ini dapat menjadi pendukung teori asal usul suku Sakai yang disebutkan oleh Suparlan (1995) yang menyatakan bahwa telah terjadi percampuran antara suku Sakai dan suku Minangkabau diwaktu yang lampau baik itu disebabkan oleh migrasi ataupun pernikahan.

Pada suku Sakai, perolehan rata-rata nilai heterozigositas yang diamati diketahui lebih besar dibandingkan rata-rata nilai heterozigositas diharapkan yaitu $\mathrm{Ho}>\mathrm{He}(0.636 \pm 0.166>0.557$ \pm 0.062). Menurut Sheriff \& Kefyalew (2018), apabila Ho lebih besar dari He maka hal ini dapat berkaitan dengan adanya percampuran yang dilakukan oleh populasi yang sebelumnya terisolasi (isolate-breaking effect). Hal ini selaras dengan proses berkembangnya suku Sakai yang berawal dari proses ekspansi pencarian minyak bumi besar-besaran oleh PT Calatex hingga ke pelosok-pelosok hutan untuk pembukaan ladang minyak di belantara hutan Riau. Hal ini menyebabkan kebudayaan luar dikenal dan mulai masuk perlahan-lahan kedalam masyarakat suku Sakai yang sebelumnya menghabiskan dan menggantungkan hidupnya dengan berpindahpindah di pinggir sungai dan pedalaman hutan Riau. Masuknya kebudayaan luar tersebut kedalam populasi suku Sakai membuat sebagian masyarakat Sakai mulai terlepas dari keterbelakangan dan menyebabkan terjadinya beberapa perkawinan antara masyarakat suku Sakai dengan masyarakat luar seperti suku Melayu, suku Minangkabau dan suku lainnya (berdasarkan Wawancara dengan Bapak $M$. Yatim, selaku tokoh adat suku Sakai pada 22 Januari 2019 di Desa Kesumbo Ampai Kacamatan Bathin Solapan). Persebaran alel-alel pada suku Sakai selain datang dari suku Minangkabau, kemungkinan juga dapat berasal dari suku lainnya berdasarkan penemuan alel-alel yang memiliki kisaran yang sama. Hal ini semakin diperkuat dengan tidak adanya pembatasan pernikahan pada masyarakat adat suku Sakai sehingga menyebabkan perkawinan campur antara suku Sakai dengan suku luar lainnya tidak dapat dihindari.

Perolehan rata-rata nilai diferensiasi genetik (F'sт) antara suku Sakai dan suku Minangkabau diketahui berada ditingkat sedang yaitu berada di nilai $0,088 \pm 0,039$. Pengelompokan nilai perbedaan genetik ini berdasarkan Nei (1973), apabila nilai $\mathrm{F}_{\text {'sT }}<0,05$ menunjukkan perbedaan genetik yang rendah, F' sT 0,05-0,15 menunjukkan perbedaan genetik yang sedang, F'sт $0,15-0,25$ menunjukkan perbedaan genetik yang tinggi dan F'sT > 0,25 menunjukkan perbedaan genetik yang sangat tinggi (Nei, 1973). Berdasarkan perolehan rata-rata nilai diferensiasi genetik (F'sT) pada tingkat sedang tersebut dapat dikatakan bahwa 
suku Sakai dan suku Minangkabau secara genetik masih memiliki kemiripan satu dengan lainnya.

Keragaman genetik dan perbedaan genetik yang sedang antara suku Sakai dan suku Minangkabau ini mengindikasikan adanya aliran genetik pada kedua populasi ini melalui proses migrasi dan percampuran yang mungkin telah terjadi jauh sebelum ekspansi pencarian minyak bumi oleh PT Caltex atau pada saat arus kedatangan dan masuknya suku pendatang ke Riau. Laju migrasi pada suku Sakai dan suku Minangkabau menunjukkan $\mathrm{Nm} \geq 1$ yang berarti pada kedua populasi ini terjadi aliran gen yang cukup untuk terjadinya pepindahan alel (Bahagiawati dkk., 2010). Diketahui adanya aliran keluar atau masuknya orang dari kedua suku ini sebanyak empat orang setiap generasi $(3,729 \pm 1,348)$. Selain itu, data kecilnya perolehan jarak genetik (Genetic distance) antara suku Sakai dan suku Minangkabau $(0,269)$ semakin mendukung kemiripan antara kedua suku ini secara genetik. Apabila jarak genetik antara suku Sakai dan suku Minangkabau semakin kecil, maka akan menyebabkan nilai proporsi gen yang identik (Genetic identity) akan semakin besar $(0,764)$ dikarenakan semakin dekat hubungan antara kedua suku ini.

\section{SIMPULAN}

Variasi genetik yang dimiliki suku Sakai dan suku Minangkabau berada di tingkat keragaman genetik sedang dengan ragam alel yang ditemukan pada suku Sakai yaitu sebanyak 10 ragam alel (empat alel tersebar dalam lokus D2S1338, empat alel pada lokus D16S539 dan dua alel pada lokus D13S317) dan pada suku Minangkabau ditemukan 11 ragam alel (empat alel tersebar dalam lokus D2S1338, empat alel pada lokus D16S539 dan tiga alel pada lokus D13S317). Berdasarkan tiga lokus DNA mikrosatelit ini, ditemukan adanya laju migrasi sebanyak empat orang per generasi dan kecilnya jarak genetik antara suku Sakai dan suku Minangkabau sehingga menyebabkan proporsi gen yang identik antara kedua suku ini semakin besar.

\section{UCAPAN TERIMA KASIH}

Kepada masyarakat adat suku Sakai di Kabupaten Bengkalis dan suku Minangkabau di Desa Pagaruyung yang telah bersedia menjadi probandus dalam penelitian ini dan semua pihak yang telah membantu menyelesaikan penelitian dan tulisan ini, penulis ucapkan banyak terimakasih. Selain itu penulis juga mengucapkan terimakasih kepada kepala Laboratorium Serologi dan DNA Forensik UPT Forensik Universitas Udayana dan Kepala Laboratorium Biologi Sel dan Molekuler Fakultas Kedokteran Universitas Udayana yang telah memberikan izin penggunaan fasilitas laboratorium kepada penulis untuk melakukan penelitian.

\section{KEPUSTAKAAN}

Arnila GAP, Junitha IK, Pharmawati M. 2016. Variasi Genetik Masyarakat Soroh Pande di Kabupaten Gianyar Berdasarkan Tiga Lokus DNA Mikrosatelit Autosom. Jurnal Biologi 20(1): $1-5$.

Agnes RS, Ahmad A. 2007. "Runtuhnya Kearifan Suku Sakai," Bagian 2. Harian Kompas, Rabu, 25 April 2007

Bahagiawati, Utami DW, Buchori D. 2010. Pengelompokan dan Struktur Populasi Parasitoid Telur Trichogrammatoidea armigera pada Telur Helicoverpa armigera pada Jagung Berdasarkan Karakter Molekuler. Jurnal Entomologi Indonesia 7(1): 54-65.

Butler JM. 2006. Genetics and Genomics of Core Short Tandem Repeat Loci Used in Human Identity Testing. Journal Forensic Science 51(2): 253-265.

Daldjoeni N. 1991. Ras-Ras Umat Manusia. Citra Aditya Bakti: Bandung

Damayanti IAM., Junitha IK, Suaskara IBM. 2014. Variasi Genetik Soroh Brahmana Budha Di Bali Berdasarkan Penanda DNA Mikrosatelit Kromosom-Y. (Skripsi). Jurusan Biologi. Fakultas Matematika dan Ilmu Pengetahuan Alam. Universitas Udayana. Bali.

Dwitiari MC. 2012. Variasi Genetik Masyarakat Bali Mula di Desa Sembiran Buleleng 
dengan Penanda DNA Mikrosatelit. Jurnal Biologi 16(1): 9-14.

Gonser R, Donnely P, G. Nicholson, dan A. Di Rienzo. 2000. Microsatellite Mutation and Infernces About Human Demography. Genetics 154(4): 1793- 1807.

Hutchinson F. 2001. DNA Band Size Semi-log Plotting. Cancer Research Center Science Education Partnership

Junitha IK. 2004. Keragaman Genetik Masyarakat di Desa-Desa Bali Aga Berdasarkan Analisis DNA dan Sidik Jari. Bogor. Sekolah Pascasarjana Institut Pertanian Bogor. (Disertasi). Tidak Dipublikasikan

Junitha IK, Octavia LE. 2015. Studi Pendahuluan Variasi Genetik Masyarakat Dayak di Kota Palangka Raya Kalimantan Tegnah Berdasarkan Enam Lokus Mikrosatelit Autosom. Prosiding Seminar Nasional Biosains hal. 242-247

Junitha IK, Sudirga SK. 2007. Variasi DNA Mikrosatelit Kromodom Y pada Masyarakat Bali Terunyan. Hayati Journal of Bioscience 14(2):59-64

Junitha IK, Watiniasih NL. 2014. Male Genetic Diversity of Siwa Brahmin Clan in Bali based on Y-Chromosomal Microsatellites DNA. Journal of Biology Agriculture and Healthcare 4(1): 30-35.

Junitha IK., Yossy C. 2016. Ragam Alel Dan Kekuatan Pembeda Lima Lokus Mikrosatelit Dna Autosom Masyarakat Suku Batak Di Denpasar dan Badung. 2016. Indonesian Journal of Legal and Forensic Sciences 6: 610.

Kurtubi D. 2017. "Mengenal Suku-Suku Asli (Komunitas Adat Terpencil) Di Provinsi Riau" tersedia dalam http://dinsos.riau.go.id/web/index.php?optio n=com_content\&view=article\&id=410:men genal-suku-suku-asli-komunitas-adatterpencil-di-provinsi-riau-oleh-dodi-ahmadkurtubi\&catid $=17 \&$ Itemid $=117$ diakses pada 10 September 2018.

Laksmita AS, Junitha IK, Watiniasih NL. 2015. Struktur Genetik dan Ragam Alel Tiga Generasi Masyarakat Bali Berdasarkan Lima Lokus Penanda DNA Mikrosatelit Autosom. Metamorfosa 2(2): 58-65
Lutfi M. 1977. Sejarah Riau. Pekanbaru: Universitas Riau Press.

Maruyama S, Minaguchi K, Takezaki N, Nambiar P. 2008. Population data on 15 STR loci using AmpF/STR Identifiler kit in a Malay population living in and around Kuala Lumpur, Malaysia. Legal Medicine 10: 160162.

Moeljopawiro S. 2010. Marka Mikrosatelit sebagai Alternatif Uji BUSS dalam Perlindungan Varietas Tanamam Padi. Balai Besar Penelitian dan Pengembangan Bioteknologi dan Sumberdaya Genetik Pertanian. Buletin Plasma Nutfah 16(1):1-7

Muladno. 2000. Polimorfisme Dan Analisis Keterpautan Mikrosatelit Pada Genom Babi. Hayati 7(1): 11-15.

Mulliadi D, Johar A. 2010. Pendugaan Keseimbangan Populasi dan Heterozigositas Menggunakan Pola Protein Albumin Darah pada Populasi Domba Ekor Tipis (Javanese Thin Tailed) di Daerah Indramayu (Prediction Equilibrium of Population Used Blood Albumin Pattern of Thin Tailed Sheep Pop). Jurnal Ilmu Ternak 10(2): 65-72.

Nanasato Y, Uenoyama R, Tomooka K, Kato A, Akashi K. Nuclear isolation and purification using SDS/urea (NIPSU) method for efficient and rapid extraction of high-purity genomic DNAs from Jatropha curcas L: A comparative analysis of DNA isolation protocols. African Journal of Biotechnology 17(32): 981-988.

Nei M. 1973. Analysis of gene diversity in subdivided populations. Proceedings of the National Academy of Sciences of the United States of America 70(12): 3321-3.

Nur'aisyah. 2017. Adaptasi Suku Asli Di Desa Jangkang Kecamatan Bantan Kabupaten Bengkalis. Jom FISIP. 4 (2): 1-15.

Octavia, LE, Junitha IK, Narayani I. 2015. Variasi Alel DNA Mikrosatelit Autosom Lokus D2S1338, D13S317 Dan D16S539. Jurnal Biologi 19(2):69-73.

Pasaribu P. 2019. Manajemen Istano Basa Pagaruyung. Jurnal Pariwisata 6(1):71-79.

Peakall R, Smouse PE. 2012. GenAlEx 6.5: Genetic Analysis in Excel. Population Genetic Software for Teaching and Research - an Update. Bioinformatics 28(19): 25372539. 
Rodriguez JJRB, Jazelyn MS, Gayvelline CC, Rita PL, Maria CADU. 2015. Allele frequencies of 23 autosomal short tandem repeat loci in the Philippine population. Legal Medicine 7(4):295-7.

Sharma R, Brijesh K, Reena A, Sonika A, Mishra AK, Tantia MS. 2016. Genetik diversity estimates point to immediate efforts for conserving the endangered Tibetan sheep of India. Meta Gene 8:14-20 .

Sheriff O, Kefyalew A. 2018. Genetik diversity studies using microsatellite markers and their contribution in supporting sustainable sheep breeding programs: A review. Cogent Food \& Agriculture 4: 1459062.
Sofyan A. 2012. Sejarah Perkembangan Bahasa Sakai. Linguistika: Buletin Ilmiah Program Magister Linguistik Universitas Udayana 19 Sep 2012. Tersedia dalam: https://ojs.unud.ac.id/index.php/linguistika/a rticle/view/9692 diakses pada 10 September 2018.

Suparlan P. 1995. Orang Sakai di Riau: Masyarakat Terasing dalam Masyarakat Indonesia. Jakarta: Yayasan Obor.

Unadi YC, Narayani I, Junitha IK. 2010. Variasi Genetik Suku Batak yang Tinggal di Kota Denpasar dan Kabupaten Badung Berdasarkan Tiga lokus mikrosatelit DNA Autosom. Jurnal Biologi 14(2): 33-38. 